\title{
SINFONIAORKESTERI-INSTITUUTION KOTOISTAMINEN SUOMESSA
}

Suomessa on kaksikymmentä valtionapua nauttivaa kaupunginorkesteria. Niistä kolmetoista on muodoltaan sinfoniaorkestereita ja seitsemän niin sanottuja kamari- tai runko-orkestereita, joiden kokoonpanoa voidaan tarvittaessa laajentaa avustajilla. Kolmentoista kaupunginorkesterin lisäksi myös Radion sinfoniaorkesteri ja Suomen kansallisoopperan orkesteri ovat sinfoniaorkestereita.

Näiden orkestereiden kuten monien muidenkin musiikillisten organisaatioiden synty ja historia on usein kerrottu kansallisena tai paikallisena sankaritarinana, jossa kotimaisten ja paikallisten voimien luovaa panosta ja toiminnan kansallista omaleimaisuutta on korostettu. Esimerkiksi Helsingin kaupunginorkesterin perustamisesta vuonna 1882 Erkki Salmenhaara toteaa, että "[m]usiikinhistoriamme aikakirjat eivät väsy toistamasta [Robert Kajanuksen] pioneerityön merkitystä" (Dahlström \& Salmenhaara 1995: 493). Todellisuudessahan Fredrik Pacius oli järjestänyt konsertteja jo 1830-luvulta lähtien, ja vuodesta 1860 alkaen kaupungissa toimi sinfonioita esittänyt ammattimainen orkesteri jokaisella soitantokaudella. Nämä orkesterit unohti myös Oskar Merikanto jo 1892 kirjoittaessaan Päivälehteen otsikolla "Orkesterimme 10-vuotisen olemassaolon johdosta":

\footnotetext{
Nuorena, säveltaiteen innostuttamana, suomalaisena taiteilijana arvasi opintomatkoiltaan palannut Robert Kajanus suuren puutteen silloisessa musiikkielämässämme: pääkaupungissa näet ei vielä ollut konserttiorkesteria (Pl 14.10.1892).
}

(c) SES \& Olli Heikkinen, Etnomusikologian vuosikirja 2018, vol. 30, ss. 6-34. 
Kajanuksen palatessa opintomatkoiltaan kesällä 1882 Helsingfors Konsert-Orkester oli pitänyt viimeisen sinfoniakonserttinsa 3.5.1882. Kajanuksen orkesterin suurin ero edellisiin orkestereihin oli kapellimestarin kansallisuus. Kajanus oli suomalainen. Suomalaisuutta ja suomen kieltä ajaneille fennomaaneille tämä oli kansakunnan rakennusprojektin kannalta merkittävä piirre (ks. Heikkinen 2018).

Artikkelissani tutkin, miten sinfoniaorkesteri-instituutio levisi Suomeen ja miten se kotoistettiin paikallisiin olosuhteisiin Porissa, Turussa ja Helsingissä. Erityistä huomiota kiinnitän diskurssiin, jossa kulttuurinen kategoria "varsinainen taidemusiikki" 180o-luvun lopulla luotiin, legitimioitiin, sakralisoitiin ja dramatisoitiin sinfoniakonserteissa. Jo olemassa olevan tutkimuskirjallisuuden uudelleentulkinnan lisäksi lähdemateriaalinani ovat aikakauden sanoma- ja aikakauslehdet.

Sanoma- ja aikakauslehtien tutkimisessa olen hyödyntänyt Kansalliskirjaston digitoidun aineiston hakutoimintoa. Olen tehnyt hakuja muun muassa sanoilla musiikkitaide, musikkonst, taidemusiikki, konstmusik, säveltaide ja tonkonst. Näiden hakujen avulla olen löytänyt kaksi keskeistä tapahtumaa, joissa diskurssi "varsinaisesta taidemusiikista" ja siihen liittyvistä kategorioista on ollut keskeinen: Vaasan laulu- ja soittojuhlat 1894 ja Helsingin Filharmoonisen Seuran orkesterin tulevaisuus 1912 senaatin lakkautettua valtiontuen. Näihin paneudun artikkelissani tarkemmin. Porin kaupungin orkesteritoimintaa olen tutkinut itseni ja tutkimusassistenttini Nuppu Koiviston keräämän sanomalehtiaineiston perusteella. Turun ja Helsingin tapauksissa olen hyödyntänyt aiempaa tutkimuskirjallisuutta (Andersson 1952; Eskelinen 1990; Korhonen 2015; Marvia \& Vainio 1993; Rosas 1965) sitä tarvittaessa sanomalehtiaineistolla täydentäen ja tarkentaen.

\section{Instituutiot ja organisaatiot}

Instituution määritelmiä on lukuisia, ja ne saattavat lähestyä kohdettaan hyvinkin eri lähtökohdista. Yhteistä kaikille kuitenkin tuntuu olevan, että mikään sattumanvarainen, ainutkertainen ja täysin yksilöllinen toiminta, tapahtuma tai ilmiö ei voi olla instituutio. Tämän voi ilmaista vaikkapa seuraavasti: 
Instituutio asettuu yksilön yläpuolelle. Se käsittää ihmisryhmiä, jotka ovat keskenään jonkinlaisen mallin mukaisessa vuorovaikutuksessa, joka on ennustettavissa ja joka perustuu tarkoin määriteltyihin toimijoiden välisiin suhteisiin (Peters 2012: 19; kaikki käännökset Olli Heikkisen).

Ronald L. Jepperson (1991: 144-145) antaa esimerkkeinä instituutioista muun muassa avioliiton, palkkatyön, kädenpuristuksen, motellin ja armeijan. Se, mikä näitä hyvin erilaisia instituutioita yhdistää, on hänen mukaansa se, että ne kaikki ovat "kroonisesti toistettuja toimintasekvenssejä".

Luodakseen viitekehyksen, jolla hyvin erilaisia käsityksiä instituutioista voidaan vertailla, W. Richard Scott (2014: 59-70) on kehitellyt erittäin käyttökelpoisen instituutioiden kolmen pilarin mallin. Näistä pilareista hän käyttää nimityksiä regulatiivinen, normatiivinen ja kulttuurikognitiivinen.

Regulatiivinen pilari viittaa instituutioiden toimintaa rajoittavaan ja ohjaavaan puoleen. Instituutiot voivat sisältää sääntöjä, tarkkailua ja rankaisemista. Regulatiivisen pilarin legitimiteetti perustuu lakiin ja sääntöihin. (Scott 2014: 59-61.) Jeppersonin mainitsemista esimerkeistä armeija varmaankin on se, joka vankimmin seisoo regulatiivisen pilarin päällä.

Myös normatiivinen pilari sisältää toimintaa ohjaavia, arvioivia ja pakottavia elementtejä, mutta erotuksena edellisestä regulatiivisesta pilarista tämä pilari korostaa (usein) julkilausumattomia arvoja ja normeja niiden takana. Arvot ja normit saattavat myös luoda instituutioon erilaisia rooleja. Varsinkin varhaiset sosiologit Émile Durkheimista Talcott Parsonsiin korostivat normien keskeisyyttä instituutioissa. (Scott 2014: 64-65.) Jeppersonin esimerkeistä tuntuisi avioliitto lepäävän eniten juuri tämän pilarin päällä. Vaikka avioliittoa sääntelee lainsäädäntö, aviopuolisoiden keskinäisiä rooleja säätelevät arvot ja normit.

Kolmas, ja käsillä olevan aiheen kannalta tärkein pilari, on kulttuurikognitiivinen. Varsinkin antropologit ja sosiologit painottavat instituutioihin sisältyviä yhteisiä käsityksiä sosiaalisesta todellisuudesta sekä tulkintakehyksiä, joiden läpi merkitys muodostuu. Merkityksen muodostumisessa keskeistä on luokittelu ja siihen sisältyvät intressit. (Scott 2014: 66-67.) Kuten Mary Douglas (1982: 12) asian kiteyttää, "kulttuuriset kategoriat ovat kognitiivisia säiliöitä, joissa sosiaaliset intressit määritellään ja luokitellaan ja joissa niistä väitellään, neuvotellaan ja taistellaan". Symbolisten rajojen "dramatisointia" institutionaalisissa rituaaleissa 
pidetään usein enemmän "pyhänä" kuin sitä, mikä rajojen kummallakin puolella sijaitsee (Wuthnow 1989: 58). Mitä ilmeisimmin sinfoniaorkesterin järjestämää sinfoniakonserttia sille erikseen tarkoitetussa konserttitilassa voidaan pitää esimerkkinä tämän kaltaisesta dramatisoinnista (rituaalisesta dramatisoinnista ks. Wuthnow 1989: 104-109).

Kolmen pilarin mallin pohjalta Scott päätyy seuraavaan instituution määritelmään: "Instituutiot sisältävät regulatiivisia, normatiivisia ja kulttuurikognitiivisia elementtejä, jotka niihin liittyvien toimintojen ja resurssien kanssa tarjoavat vakautta ja merkitystä sosiaaliseen elämään" (Scott 2014: 56).

Huomion kiinnittäminen niihin diskursseihin, joissa vanhoja tai uusia uskomuksia, normeja ja käytäntöjä pyritään legitimoimaan tai delegitimoimaan, on yksi määrittävä tekijä niin sanotussa uusinstitutionalismissa, varsinkin sen uusimmassa, diskursiivisessa versiossa (Alasuutari 2015; Schmidt 2008). Kolmesta pilarista se tukeutuu vahvimmin kulttuurikognitiiviseen pilariin ja ottaa institutionaalisen muutoksen selittämisessä ideat ja diskurssit vakavasti (ks. Schmidt 2010.)

Globaalien mallien soveltamisesta paikallisiin olosuhteisiin ja toimijoiden omiin intresseihin Pertti Alasuutari kirjoittajaryhmineen (2013) käyttää suomenkielistä termiä "kotoistaminen" (domestication, ks. Schmidt 2008). Sinfoniaorkesteri-instituutio tuli ulkomailta, ja diskursiivinen institutionalismi auttaa paremmin ymmärtämään niitä kiistoja ja neuvotteluita, joiden välityksellä instituutiot kotoistettiin osaksi suomalaista kulttuurikeskustelua ja kaupunkien musiikkielämää. Musiikillisissa keskuksissa, kuten Leipzigissa ja Berliinissä, koulutuksen saaneet muusikot levittivät globaaleja musiikillisia ideoita ja malleja, jotka suuremmissa kaupungeissa (esim. Boston; ks. DiMaggio 1982a; 1982b) toteutettiin sellaisinaan, mutta pienemmissä kaupungeissa (esim. Pori) sovellettuina ja kotoistettuina käytettävissä oleviin vähäisempiin resursseihin.

Toinen uusinstitutionalismin lähtökohta, jota pidän hyödyllisenä pyrittäessä ymmärtämään sinfoniaorkesteri-instituution kotoistamista, on instituution ja organisaation välisen suhteen määrittely. Puhekielessä, ja usein myös tutkimuskirjallisuudessa, termejä instituutio ja organisaatio käytetään toistensa synonyymeinä. Tutkimuksessa niiden erillään pitäminen teoreettisesti on kuitenkin hedelmällistä. 
Vanhemmassa institutionalismissa, jota edustivat muun muassa amerikkalaiset sosiologit Robert Merton, Philip Selznick ja Talcott Parsons, organisaation katsottiin institutionalisoituvan, jos sen "päämäärät ja toiminnot saavat vakiintuneen ja arvolatautuneen statuksen" (Selznick 1949, sit. Scott 2015: 24). Nykyisin tämä ajattelutapa on säilynyt sananparressa "on tullut instituutio", kuten esimerkiksi otsikossa "UMo:sta on tullut instituutio" (Murtovaara 2005).

Uusinstitutionaalisessa tulkinnassa osat ovat vaihtuneet. Organisaatiot ovat kuin joukkueita. Ne ovat mukana pelissä, jonka säännöt määrittelee instituutio (North 1990: 4). Niinpä esimerkiksi alussa mainitut Suomen 15 sinfoniaorkesteria pelaavat peliä, jonka säännöt sanelee sinfoniaorkesteri-instituutio. Tämä ei kuitenkaan tarkoita, etteikö sääntöjä voisi soveltaa paikallisesti eli kotoistaa. Jos jalkapalloa pelataan kuusihenkisin joukkuein, on se silti jalkapalloa. Samoin jos sinfonian esityksessä patarummut korvataan bassorummulla, voidaan sitä silti pitää sinfonian esityksenä.

\section{"Varsinainen taidemusiikki"}

Kirjassaan The Invention of "Folk Music" and "Art Music" (2007) Matthew Gelbart osoittaa, että 170o-luvulla musiikin luokittelussa tapahtui selvä muutos. Vielä vuosisadan alkupuolella käsitteiden "luonto", "tiede" ja "taide" välillä ei ollut vastakkainasettelua, vaan tiede ja taide olivat ikään kuin luonnon jatke: niiden tuli jäljitellä luontoa ja sen sääntöjä (Gelbart 2007: 40-41). Nykyään tästä esteettisestä ideaalista käytetään nimitystä imitaatioestetiikka. (ks. esim. Abrams 1960: 30-46.) Muutos tapahtui 176o-luvulta lähtien, ja keskeistä siinä oli uudenlainen käsitys historiasta lineaarisena, teleologisena, edistyksellisenä ja universaalina tapahtumaketjuna. Sen mukaan ihmiskunta kehittyy pois alkuperäisestä luonnontilastaan kohti jotain muuta. Se, mitä se muu tulisi olemaan, vaihteli kirjoittajien mukaan. Olennaista kuitenkin oli käsitys, että sivilisoituminen (ja sen mukana taiteen ja tieteen kehitys) merkitsi erkaantumista luonnosta. Näin ollen tiedettä ja taidetta ei enää käsitetty luonnon jatkeeksi vaan jyrkimmillään jopa sen vastakohdaksi. (Gelbart 2007: 41-42, 51; Nisbet 1969: 139-140; ks. myös Heikkinen 2013: 100-102.) 
Käsitys "luonnonmusiikista" ja sille vastakkaisesta "taidemusiikista" löytyy myös Suomen sanomalehdistä 18oo-luvulla. Varhaisin luonnonmusiikki-termi lehdissä on todennäköisesti vuodelta 1860 (Vbl 23.6.1860). Artikkeli, ilmeisesti ruotsalaisesta lehdestä kopioitu, käsittelee Ruotsin säveltaidetta (tonkonst) ja kansallista musiikkia yleensä (nationell musik). Kirjoittaja pohtii, onko heillä säveltaidetta, jossa olisi kansallinen ruotsalainen henki, ja vastaa sitten, että ruotsalaisten luonnonmusiikista (naturmusik) se löytyy, mutta taidemusiikista (konstmusik) ei. Tarkemmin hän ei jakoa luonnonmusiikkiin ja taidemusiikkiin selitä. Jako oli sen aikaiselle sanomalehden lukijalle kaiketi ilmiselvä - näin ainakin kirjoittaja on ajatellut. Tämä näkemys luonnon ja taiteen vastakkaisuudesta myötäilee täysin sitä näkemystä, joka syntyi 1700-luvun lopulla ja jota Gelbart kirjassaan kuvaa. Mielenkiintoista tässä kirjoituksessa on kuitenkin se, että niin luonnonmusiikki kuin taidemusiikki nähdään kuuluvan kansalliseen säveltaiteeseen. Sen minkä sivilisoitumisprosessi oli erottanut, sen nationalismi oli yhdistänyt.

Seuraavana vuonna tuntematon kirjoittaja pohtii Filip von Schantzin Kullervoalkusoittoa ja toteaa, että siitä tulisi populääri sanan parhaassa merkityksessään, jos se olisi enemmän suomalainen. Samalla hän toteaa, että taidemusiikki on enemmän tai vähemmän kosmopoliittista, mikä jättää kansanlauluille tehtävän heijastaa kansallisuuksia (Bm 6.9.1861). Tässäkin kirjoituksessa taidemusiikki ja kansanmusiikki muodostavat bipolaarisen parin, seikka, jota Gelbart kirjassaan korostaa. Vastaava näkemys nousee esiin samana vuonna julkaistusta Norjaa ja sen kansaa kuvaavasta artikkelista. Kirjoittaja kertoo ilolla kuuntelevansa tunturien asukkaiden (fjäldfolket) säveliä, jotka eivät aina noudata nykyajan sääntöjä, mutta siitä huolimatta ovat syvällisempiä ja miellyttävämpiä kuin suuri osa nykyistä taidemusiikkia ( $\mathrm{Fw} 23 \cdot 10.1861)$.

Musiikillisten kategorioiden merkitys alkoi 1880-luvulla muuttua. Säveltaide tai musiikkitaide (tonkonst, musikkonst) termeinä säilyttivät merkityksensä. $\mathrm{Ne}$ tuntuivat edelleenkin viittaavan kaikenlaiseen musisointiin, mikä ilmenee esimerkiksi eräästä Wiipurin Uutisten jutusta vuodelta 1888. Siinä kuvataan, mitä "musiikkitaiteen ihailija" saattoi kuulla kesäisessä Lappeenrannassa. Pataljoonat olivat kokoontuneet yhteisiin harjoituksiinsa, ja kun yhdeksän sotilassoittokuntaa soitti, niin "siin' on porakka". Myös kylpylaitoksella ja esplanadilla oli soitantoa joka ilta, ja soittivatpa vielä venäläiset sotamiehetkin käsiharmoonejaan 
linnan valleilla (wU 25.7.1888). Jos venäläisten sotamiesten käsiharmoonin soittokin oli "musiikkitaidetta", käsitteen kattavuus on laaja - ainakin laajempi kuin puhuttaessa "esittävästä säveltaiteesta", josta myöhemmin muodostui hyvinkin tarkkarajainen määrite (Huttunen 2002).

Sen sijaan termin taidemusiikki (konstmusik) merkitys alkoi jakautua. Esimerkiksi Wasa Tidningin (27.3.1887) arviossa paikallisen musiikkiyhdistyksen helppotajuisesta konsertista teki toimittaja jo selkeän eron "populäärin" ja taidemusiikin välillä. Edelliseen kuului kvartettilaulu ja tenorisoolo, mutta muu ohjelma sisälsikin "useita kauniita taidemusiikin tuotteita", kuten Vieuxtempsin viulunumeron. Seuraavana vuonna mahdollisesti sama toimittaja (nimimerkki "tz") kirjoitti Cherubinin Requiemin esityksestä ja totesi, että tällaisessa "taidemusiikissa ahtaammassa merkityksessä" on alukkeet ja teeman kuljetukset aina tuotava selvästi esiin (Vbl 11.4.1888).

Kun Musikaliska Sällskapet i Åbo täytti 100 vuotta vuonna 189o, julkaisi Åbo Underrättelser (25.1.1890) seuran historiikin. Siinä kerrottiin seuran orkesterin teatterisoitosta, mutta mainittiin, että "varsinaista taidemusiikkia" (egentliga konstmusiken) soitettiin edelleen konserteissa - laulunäytelmien laulut ja näytösten väliajoilla soitettu musiikki eivät sitä siis olleet. Vaasassa toimittaja puolestaan harmitteli pianisti Alfred Reisenauerin konserttien vähäistä yleisömäärää ja epäili, ettei vaasalaisten musiikkimaku koskaan kehity yksinkertaisesta laulumusiikista kohti "varsinaisen taidemusiikin" aluetta (Vbl 8.2.189o). Todennäköisesti sama toimittaja lähetti nimimerkillä W.R. myös Åbo Underrättelseriin (19.2.1890) kirjeen, jossa hän totesi Vaasan yleisön tyytyvän mielihyvin "ei-varsinaiseen" (oegentlig) taidemusiikkiin, eli "kotoisiin lauluihin ja lupsakoihin kvartetteihin".

Edelliset näkemykset eivät olleet yksityisiä mielipiteitä, vaan osa yleistä merkityksen muutosta 180o-luvun lopulla. Ristiriita "varsinaisen" taidemusiikin ja "ei-varsinaisen" kvartetti- ja muun populaarilaulun välillä konkretisoitui ja sai valtakunnallista näkyvyyttä, kun Kansanvalistusseura järjesti vuoden 1894 lauluja soittojuhlan Vaasassa. Vaasan musikaalinen yhdistys ehdotti juhlan yhteyteen järjestettäväksi "osaston korkeampaa taidemusiikkia" (högre konstmusik) (us 29.1.1893; Vbl 1.2.1893). Tämä myös toteutui. Juhlakonsertissa Martin Wegelius, Robert Kajanus, Jean Sibelius, Armas Järnefelt ja Richard Faltin johtivat omia sävellyksiään. Tämän lisäksi musikaalinen yhdistys järjesti esitykset kolmesta oratoriosta, joiden soolo-osiin oli palkattu Alma Fohrström, Maikki Pakarinen, Ale- 
xandra Ahnger, Sigfrid Westerlind, Hjalmar Frey sekä Leipzigista kamarilaulaja Karl Dierich. Erillisiä konsertteja pitivät myös viulisti Willy Burmester ja laulaja Maikki Pakarinen (myöh. Järnefelt-Palmgren) säestäjänään Armas Järnefelt. (Ohjelmasta tarkemmin ks. Rantanen 2013: 245-247; Smeds \& Mäkinen 1984: 44-45.)

Juhlan kulkua seurattiin lehdissä päivittäin kautta Suomen. Sähkösanomat mahdollistivat nopean tiedonkulun, ja juhla oli ehkä vuoden seuratuin tapahtuma Suomessa. Arviot olivat pääosin myönteisiä. Yleisellä tasolla korostettiin musiikkijuhlien sivistävää ja valistavaa voimaa. Mutta myös soraääniä esiintyi. Osa niistä liittyi kieliriitoihin - juhla oli kaksikielinen. Osa liittyi säätyläisten ja muun väestön luokkaeroihin. Valtaosa juhlaväestä kuului ylempään säätyyn, ja - päinvastoin kuin edellisissä laulu- ja soittojuhlissa - muita yhteiskuntaluokkia tapahtumassa oli vähän.

Edellisiin seikkoihin osittain liittyen myös juhlan musiikillinen linja aiheutti keskustelua, josta vähin ei ollut konserteissa esitetyn ohjelmiston sopivuus Kansanvalistusseuran juhlaan. Erään kirjoittajan mukaan talonpoikainen yleisö ei menettänyt mitään, vaikkei se juhlakonserttiin osallistunutkaan, koska tapahtuman ohjelma ei ollut tavallisen kansankokouksen sulatettavissa (US 24.6.1894). Toisen mielestä juhlan ohjelma vaikutti enemmän musiikki-intoilijoiden orgialta kuin yksinkertaiselta mutta ylevältä ja isänmaalliselta koko kansalle tarkoitetulta juhlalta (̊̊T 26.6.1894). Ihmetystä herätti myös se, että Faltin, Kajanus ja Wegelius kieltäytyivät osallistumasta kuoro- ja torvisoittokilpailun palkintolautakuntaan, vaikka heidät oli siihen aiemmin ilmoitettu (NPr 26.6.1894). Syytä tähän ei lehdessä osattu kertoa, mutta ainakin Wegeliuksen vastenmielisyys torvisoittoa kohtaan oli tiedossa. Kun Turun Soitannollinen Seura vuonna 1876 haki orkesterilleen kapellimestaria, Wegelius arvioitiin hakijoista pätevimmäksi, mutta ei tullut valituksi, koska hän hakijoista ainoana kieltäytyi johtamasta torvimusiikkia (Korhonen 2015: 169).

Mutta kritiikkiä sai myös yleisö. Säveltäjä Oskar Merikanto oli hyvin närkästynyt siitä, että oratoriokonserteissa yleisöä oli vähän ja Willy Burmesterin konsertissa vieläkin vähemmän, samaan aikaan kun Ylioppilaskunnan Laulajien ja Akademiska Sångföreningenin konserteissa oli "porstuakin täynnä", siitäkin huolimatta, että kuorojen konsertit olivat "diletanttikonsertteja" (Pl 26.6.1894). Syy "arvokkaiden" konserttien yleisökatoon oli Merikannon näkemyksen mukaan yleisön "maussa, käsityksessä, taiteen ja diletantismin eroittamisessa". 
Kvartettilaululle Merikanto antoi jyrkän ja yksiselitteisen tuomion:

Näiden ylioppilaskonserttien johdosta tuli ehdottomasti ajatelleeksi sitä seikkaa, että muu arvokkaampi musiikki näkyy saavan kärsiä kvartettilaulun takia. Aivan niinkuin mustalais- ja itaalialaisköörejä käydään mieluummin kuulemassa, kuin hienoa sinfoniiakonserttia, tai varieteessa mieluummin kuin hyvässä konsertissa! On kyllä totta, että helpompaa musiikkia on vaihteeksi hyvä ja hauska joskus kuulla - ja kvartettilauluahan yleensä kaikki luulevat ymmärtävänsä -, mutta tuolle helpommalle musiikille ei pitäisi antaa etusijaa, ei pitäisi päästää sitä paremman, jalomman, korkeamman musiikin, tositaiteen tielle. Sillä jos se etusijan saa - niin kuin sillä, ikävä kyllä, nyt jo näkyy monessa suhteessa olevan -, silloin ei todellinen musiikki, mieliä ja sydämiä jalostuttava taide pääse kasvamaan, edistymään, kehittymään ja hedelmää kantamaan, vaan taannutaan, laimennutaan ja jäädään hyvinkin itseensä tyytyvinä istua kököttämään diletantismin ala-arvoisille portaille. Ja sitä ei suinkaan eteenpäin pyrkivä Suomi tahtoisi enemmin tällä kuin muillakaan aloilla!

Vastakkain olivat siis korkeampi "tositaide" tai "todellinen musiikki" ja "diletantismi" tai "helpompi musiikki". Pitikö Merikanto "diletantismia" silti vielä taidemusiikkina, joskin sen "ei-varsinaisena" tai "ei-todellisena" muotona, se ei kirjoituksesta yksiselitteisesti selviä.

Armas Järnefelt ei ollut kvartettilaulun suhteen yhtään armollisempi Uuteen Suomettareen kirjoittamassaan raportissa. Kvartettilaulu, jota hänen mukaansa pidettiin Suomessa ja Ruotsissa miltei "korkeimpana musiikkitaiteen haarana", "on [...] tappanut muun musiikin Ruotsista, ja se on hyvällä alulla tekemään samoin jo täällä Suomessakin" (us 27.6.1894). Syynkin hän tietää:

He kuuntelevat sanoja ja tulevat liikutetuiksi melodiiojen sentimentaalisista

käänteistä. Heidän korvansa tottuu huonoon tahtiin ja ikäviin harmoniioihin.

Kaikesta tästä seuraa että, kun he kuulevat muuta musiikkia, varsinkin instrumentaalimusiikkia, he eivät voi seurata mukana. He eivät ymmärrä kuulemaansa ja tekevät sen johtopäätöksen, että ei se ole kvartettilaulun veroista. 
Huomionarvoista on kvartettilaulun ja instrumentaalimusiikin vastakkainasettelu. Järnefelt antaakin ohjeen, että "jos tahdotaan aikaansaada soittojuhla, jossa jalompaa musiikkia tarjotaan, suljettakoon niistä kvartettilaulu pois". Kaikenlainen laulumusiikki oli suuren yleisön keskuudessa 180o-luvulla ylivoimaisesti suosituinta. Siinä missä kansainvälisesti kuuluisat instrumentalistit joutuivat usein tyytymään vajaisiin saleihin, kvartettilaulu, laulunäytelmät, operetit, ooppera ja laulajien soolokonsertit täyttivät salit huomattavasti varmemmin. Vaikka lied-lauluun ja oratorioihin suhtauduttiin vakavasti, koostui "korkeampi taidemusiikki" kamarimusiikista ja sinfonioista, kuten esimerkiksi Aapo Similä asian paljon myöhemmin muotoili (Kal 10.11.1919, ks. myös Weber 2001; 2008).

Kuvaavaa aikakauden musiikkidiskurssille on kuvitteellinen tarina, jonka Uusi Suometar julkaisi 10.7.1894. Tarinassa kertoja kuvaa taannoista junamatkaansa. Käytävän toisella puolella istui kaksi säveltäjää "korkeamman taiteen" alalta. Toinen oli lyhyt ja pyylevä, toinen pitkä ja hoikka. Lyhyemmän sanavarastoon kuului "diletantismi", ja pidempi oli hyvin huolestunut kvartettilaulun vaikutuksesta instrumentaalimusiikkiin. Keskustelu suuntautui Vaasan musiikkijuhlaan ja sen "musikaalisen publiikin" turmeltuneeseen makuun.

Mutta, osastossa istui kolmaskin mies, sarkatakkinen, joka myös halusi lausua asiasta jotain:

[O]linpa sitä minäkin Vaasan laulujuhlassa, ja tuntui minusta, että ylioppilaslaulu siellä oli paikallaan. Eiväthän nuo "nuorukaiset" kuulu väittävänkään olevansa taiteilijoita. Tahtovathan vain yksinkertaisella laulullaan sekä muissa että itsessään herättää isänmaallista innostusta. Olihan siellä juhlassa korkeampaa musiikkia tarpeeksi, mutta sepä oli enimmäkseen hienoa yleisöä varten, jota vastoin rahvas tässä kansanjuhlassa sai tyytyä jotenkin vähään. Luulenpa, ett'ei Suomen kansa vielä ole kypsynyt noin paljon korkeampaa musiikkia kuulemaan ja sulattamaan.

Säveltäjät nyrpistivät nenäänsä ja arvelivat mielessään, että jos ei tunne "kenraalibaasin ja kontrapunktin salaisuutta", kannattaa olla puuttumatta puheeseen. Lausuttuaan vielä näkemyksenään, että "kansan maku on puhdistettava ja korkeampaan nautintoon kykeneväksi tehtävä", säveltäjät poistuivat. Sarkatakkinen ryhtyi hyräilemään toista bassoääntä erääseen kansanlauluun. 
Kvartettilaulu ei ollut 180o-luvun lopulla ainoa "ei-varsinaisen taidemusiikin" laji. Merikannon ja Järnefeltin näkemyksistä kvartettilaulua kohtaan innoittuneena päätyi "Matti" pilalehdessä Matti Meikäläinen (13.7.1894) lopulliseen ratkaisuun. Otsikolla "Matti on murhatuulella" kirjoittaja ilmoittaa aikovansa leikata kaikilta kvartettilaulajilta pään poikki: "Pilatkootpa sitte laulullaan yleisön musikaalista makua, kun ei heillä ole päätä eikä kaulaa". Muita musikaalisen maun pilaajia Matin mukaan kesällä 1894 Helsingissä olivat "punanvihreät torvipojat [...] Oopriksen edustalla ja sinikeltaisella mahavyöllä merkityt knallimusikantit Kappelin edustalla [sekä] balalaikkamusikantit vesillä ja vuorilla".

Nämä kaikki "maun pilaajat" - kvartettilaulu, torvisoitto ja balalaikkaorkesteri - ovat esimerkkejä musiikista, joka mielenkiintoisella tavalla sijoittuu sekä esteettisesti että sosiaalisesti toisaalta "korkeamman" eli "varsinaisen" taidemusiikin ja toisaalta alempien yhteiskuntaluokkien suosiman "matalamman" musiikin väliin. Tutkimuksessa tästä musiikista on käytetty nimitystä "mesomusiikki" (Vega 1966), "middle music" (Edström 1992) ja "keskimusiikki" (Kurkela 2017). Kyse on musiikista, jonka esteettiset arvot ovat hyvin pitkälti samat kuin "varsinaisessa" taidemusiikissa, mutta ne tarjoillaan kuulijoille helpommin ymmärrettävässä ja viihteellisemmässä muodossa, sivistys- ja kansanvalistusaspektia unohtamatta (ks. Kurkela 2015). Edellä mainittu Vaasan kirjeenvaihtaja kiteytti asian mainiosti: "ei-varsinainen (oegentlig) taidemusiikki" - melkein, mutta ei ihan. Samaan "keskiotsaiseen" (middle-brow, ks. Rubin 1992) kulttuuriin kuuluivat myös helppotajuiset eli populäärit luennot, joissa kansanvalistuksen nimissä tieteen saavutuksista luennoitiin kielellä, jota niin sanottu tavallinen kansakin ymmärsi.

Kitka korkea-, keski- ja matalaotsaisuuden välillä oli kuitenkin olemassa. Kokemuksiinsa Vaasan laulu- ja soittojuhlilla tukeutuen ja juhlien korkeaotsaista ohjelmistoa kritisoiden kirjoitti nimimerkki "Sirio", että "[v]aarallinen kilpailija [taidemusiikista] voi pian koitua kansanomaiselle musiikille joll'ei sitä pidetä aisoissa" (ws 28.6.1894). Jos "Sirio" tarkoitti kansanomaisella musiikilla keskimusiikkia, hänen huolensa oli varmaankin aiheellinen. Sen sijaan kansanlaululle ja kansanmusiikille taidemusiikki ei muodostanut kilpailijaa vaan liittolaisen. Kansanmusiikkilainat olivat keskeisiä sekä varsinaisessa että ei-varsinaisessa taidemusiikissa. 
Taidemusiikin ja kansanmusiikin välisen kansallisen liiton oli kiteyttänyt jo Ilmari Krohn Uudessa Suomettaressa 16.10.1891. Hän oli varma, ettei kansanmusiikki "tule sortumaan katumusiikin suuhun", vaan "nuori taidemusiikkimme on, imien itseensä kansanmusiikin hengen ja taidepuvussa antaen sen takaisin kansalle, opettava sitä rakastamaan ja säilyttämään omaisuuttaan". Seuraavana vuonna esitetyssä Jean Sibeliuksen sinfonisessa runoelmassa Kullervo tuota kansanmusiikin henkeä kuulivatkin yllin kyllin lähes kaikki kriitikot, minkä takia ensiesitys on säilynyt historiankirjoissa suomalaisen sävelkielen syntyhetkenä (ks. Heikkinen 2012).

Edellä kuvattu jako ei ollut juuriltaan kotoperäistä. Taustalla oli yleiseurooppalainen ilmiö, jota esimerkiksi William Weber on kirjoituksissaan kuvannut (Weber 2001; 2008). Weberin (2001: 129) mukaan 180o-luvun kuluessa konserttiohjelmistoissa tapahtui muutos, jonka seurauksena "ylevä" ja "vakava" teoskaanon erkaantui populaarimusiikista. Muutos tapahtui ensin 1840-luvulle tultaessa kamarimusiikissa ja hieman myöhemmin 186o-luvulla orkesterimusiikissa.

Tämän kehityksen alun Weber sijoittaa Saksiin ja Thüringeniin. Keskeisin paikka epäilemättä oli Leipzig, jonka konservatoriossa Vaasan juhlille osallistuneista olivat opiskelleet Helsingin "musiikkipaavit" Wegelius ja Kajanus, sekä Faltin ja Merikanto. Wegeliuksen Leipzigin mallin mukaisesti perustamassa musiikkiopistossa puolestaan olivat opiskelleet Kajanus ja Järnefelt. Varhaisimman soitonopetuksensa Merikanto oli saanut urkuri Lauri Hämäläiseltä. Tämä oli hankkinut koulutuksensa Tukholmassa, jossa keskeisissä musiikillisissa asemissa toimi "Leipzig-falangi" (Tegen \& Jonsson 1992: 35-36): J. A. Josephson, Ludwig Norman, August Söderman ja Albert Rubenson. Leipzigin konservatorion suurta merkitystä taidemusiikin institutionalisoitumisessa Pohjois-Saksassa ja Pohjoismaissa 180o-luvun loppupuolella ei voi kiistää (ks. myös Krummacher 1989).

Wegelius, Merikanto ja Järnefelt omaksuivat Leipzigin musiikinopetuksen ihanteita ja toivat niitä suuremman yleisön tietoisuuteen sanomalehtikirjoituksissaan - kaksi ensin mainittua säveltäjää musiikkikirjeinä suoraan Leipzigista. Esimerkiksi Uusi Suometar julkaisi 1.11.1888 Merikannon lähettämän valikoiman sitaatteja saksankielisistä lähteistä suomeksi käännettynä otsikolla "Mietteitä säveltaiteesta ja -taiteilijoista". Merikanto oli valikoinut mietelmiä niin säveltäjiltä (mm. Beethoven, Mendelssohn ja Berlioz) kuin kriitikoilta (mm. Marx, Hanslick ja Brendel). Hänen Vaasassa pohdiskelemaansa "taiteen ja diletantismin" väli- 
seen eroon liittyy ainakin seuraava sitaatti säveltäjä-historioitsija August Reissmannilta: "Salonki-musiki seisoo niin näppärästi taiteen rajalla, että sitä hyvin harvoin siihen voi lukea".

Kaikki taidemusiikkidiskurssiin osallistuneet eivät kuitenkaan olleet yhteydessä Leipzigiin, suoraan tai edes välillisesti. Osa ei ollut edes musiikkialan ammattilaisia, kuten diskurssi Vaasan laulujuhlien yhteydessä osoittaa. Juhlia kommentoineet junan sarkatakkinen mies, "Matti" ja "Sirio" eivät olleet näkemyksissään täysin yksimielisiä, mutta oleellisempaa oli, että he joka tapauksessa hyväksyivät Merikannon ja muiden Leipzigin-kävijöiden kategorisen jaottelun "korkeampaan" ja "yksinkertaisempaan" musiikkiin.

Mutta miten nämä muutokset musiikin luokittelussa vaikuttivat musiikilliseen toimintaan? Miten symboliset rajat dramatisoitiin? Lähestyn näitä kysymyksiä tarkastelemalla soitinkokoonpanoja, joita ylläpidettiin julkisin varoin kolmessa eri kaupungissa: Porissa, Turussa ja Helsingissä.

\section{Stadskapell - kaupungin soittokunta}

Soitinkokoonpanoja koskeva terminologia vaihteli 18oo-luvulla suuresti. Esimerkiksi Åbo Tidningin 27.2.1805 julkaisemassa "musiikillisessa anekdootissa" kerrotaan Joseph Haydnin ruhtinas Esterhazylle pitämästä jäähyväiskonsertista ja käytetään termejä "orkester" ja "kapell" toistensa synonyymeinä. Vaikka myös suomenkielisissä sanomalehdissä käytettiin satunnaisesti termiä "kapelli", oli "orkesterin" synonyymi useimmiten "soittokunta". Esimerkiksi Ilmarinen uutisoi 20.12.1867, että "[s]oittajaisia on kaupungissamme [Viipurissa], sittenkun kesän lopulla saatiin uusi, hra Schneevoigtin johdattama, soittokunta eli orkesteri, pidetty hyvinkin tiheästi".

Vanhimmat orkesteriperinteet Suomessa ovat luonnollisesti entisessä pääkaupungissa Turussa, jossa Akatemian yhteydessä toimi "kapelli" jo 160o-luvulla. Sen sijaan "orkesteriksi" määriteltiin Turun Soitannollisen Seuran säännöissä vuonna 1790 se soitinkokoonpano, jota seuran tuli ylläpitää. Seuran toiminta rahoitettiin jäsen- ja pääsymaksuin, ja konserttimestaria lukuunottamatta soittajat olivat harrastajia. Yksityisten konserttien lisäksi orkesteri järjesti myös julkisia konsertteja. Ne koostuivat ajan tavan mukaan hyvin monipuolisesta mutta poh- 
jimmiltaan "vakavasta" ohjelmistosta kuten sinfonioista, konsertoista, kamarimusiikista ja aarioista. (Andersson 1952.) Soitannollisen seuran esikuvina toimivat keskieurooppalaiset musiikilliset akatemiat. Ne olivat "yksityisiä seuroja, joissa huomattavat kansalaiset kokoontuivat yhteen nauttimaan musiikista sekä ylhäisön kamareita muistuttavasta ympäristöstä" (Broyles 2000: 102). Soitannollisen seuran edeltäjä Turussa oli ollut Aurora-seura, jolla taas oli tiiviit suhteet Tukholmassa vuosina 1766-1795 toimineeseen salaseura Utile Dulciin (Andersson 1952, 29-30).

Kaupungeissa oli tarvetta myös "kevyempään" musiikkiin. Se kytkeytyi usein huvielämään ja erilaisiin säestystehtäviin. Turussa tämän kaltaista musiikillista toimintaa ryhtyi vuonna 1839 järjestämään liiviläinen viulisti Wilhelm Friedrich Siber. "Siberin kapelli" ei tarjonnut säännönmukaisia konsertteja, vaan se soitti siellä, missä kaupunkilaiset musiikkia tarvitsivat: tanssiaisissa, musiikillisissa illanvietoissa, yksityisissä juhlissa ja kesäisin sekä Kupittaan että Naantalin kylpylöissä - korvausta vastaan. Siberin kapelli oli Turun ja mitä ilmeisimmin koko Suomen ensimmäinen "stadskapell". Se tavallaan jatkoi keskiajalta peräisin olevaa kaupunginmuusikkoinstituutiota, jossa kaupunkilaisten palkkaama muusikko kisälleineen ja oppipoikineen huolehti kaupungin musiikintarpeesta (Andersson 2003; ks. myös Rantanen \& Heikkinen tulossa).

Kapellin kooksi on eri lähteissä mainittu kahdeksan soittajaa (esim. Rosas 1965: 25), mutta Siber itse mainosti pystyvänsä toimittamaan tarpeen mukaan 5-15 miehisen "orkesterin" ja vieläpä "edulliseen hintaan" (̊̊ 2.1.1852). Kapelli oli "sekaorkesteri", eli se pystyi soittamaan jousimusiikin lisäksi torvimusiikkia, mihin viittaa Kupittaan konsertti-ilmoitusten termi "harmonimusik" (esim. ̊̊T 12.6.1847).

Huvielämä Pohjois-Euroopan kaupungeissa jakautui yleensä kahteen kauteen: talvikauteen ja kesäkauteen. Talvikaudella lokakuusta toukokuuhun huvielämä tapahtui sisätiloissa. Tanssiaisia, teatteriesityksiä ja illanviettoja säestämään valittiin usein jousiorkesteri, koska sen ohjelmisto oli monipuolinen ja äänenvoimakkuus kohtuullinen. Sen sijaan kesäkaudella, kun huvielämä siirtyi ulos puistoihin ja kylpylöihin, tarvittiin kauemmaksi kantavaa torvisoittoa. Kesäinen torvisoitto oli yleiseurooppalainen ilmiö, mutta sen järjestämistapa vaihteli paikallisten resurssien mukaan. Esimerkiksi Ruotsissa sotilassoittajien mah- 
dollisuudet kesäisiin lisäansioihin olivat paljon paremmat kuin Suomessa, koska kylpyläpaikkakuntia oli moninkertaisesti enemmän (ks. Nilsson 2017).

Turun kaupunki päätti vuonna 1867 perustaa uuden "musiikkikapellin" kaupungin alaisuuteen ( $₫$ U 5.9.1867). Kyseessä oli "sekaorkesteri": se esitti sekä "orkesteri- että torvimusiikkia" ( $₫$ U 25-4.1868). Kaupungin myöntämän avustuksen lisäksi tuloja aiottiin kerätä teatterisoitolla, illanvietoilla, yksityisillä esiintymisillä ja "kesämusiikilla". Aiemmasta Siberin kapellista poiketen kaupungin uusi kapelli järjesti konsertteja myös "vakavammalla" ohjelmistolla. Esimerkiksi "Stor Vokal- och Instrumental-Konsert i 3 afdelningar" 1.12 .1872 sisälsi kapellimestari Oscar Byströmin säveltämän fantasian orkesterille, kuoron Haydnin Luomisesta, kvinteton Mozartin Taikahuilusta, alkusoiton ja kuoron Weberin Oberonista ja päätteeksi Mozartin Es-duuri-sinfonian. Vakavammat konsertit olivat kuitenkin vähemmistössä. Esimerkiksi soitantokaudella 1872-1873 kapellin 175 esiintymisestä niitä oli vain kymmenen (Korhonen 2015: 163).

Syksyllä 1877 kapelli teki vierailun Poriin. Tapahtumalla oli suuri vaikutus Porin musiikkielämään. Orkesteritoiminnan kehitys oli jäänyt kaupungin pienemmän koon ja vähäisempien resurssien vuoksi Turusta jälkeen. Ensimmäiset tiedot Porin orkesteritoiminnasta ovat 180o-luvun puolivälistä, jolloin paikkakunnalla toimi muutaman vuoden kaupungin tukemana "Saksanmaalta" tilattu soitinkokoonpano. (Korhonen 2015: 136; Ruuth 1899: 411; Porin orkesteritoiminnan alkuvaiheista ks. Rantanen \& Heikkinen tulossa).

Vuonna 1859 armeijauudistuksen yhteydessä yksi uusista tarkk'ampujapataljoonista sijoitettiin Poriin. Pataljoonan signaalitorven soittajat perustivat torvisoittokunnan, joka alkoi korvausta vastaan esiintyä sekä julkisissa että yksityisissä juhla- ja huvitilaisuuksissa. Vuonna 1868 kaikki tarkk'ampujapataljoonat Suomen Kaartia lukuun ottamatta lakkautettiin, mutta Porin soittokunta jatkoi toimintaansa kaupunkilaisten tuen turvin (Rantanen \& Heikkinen tulossa).

Vaikka soittokunnan toimintaa arvioitiin lehdissä pääosin hyvin myönteisesti, yksi ongelma torvisoittokunnalla kuitenkin oli: se oli pieniin sisätiloihin liian äänekäs. Samaa ongelmaa Vaasassa kuvasi turkulaisen sanomalehden Åbo Underrättelserin kirjeenvaihtaja Thomas värikkäästi 11.10.1879: 
Syyskuun 28. päivänä annettiin "Ernstin salongissa" Vaasassa "promenadikonsertti". Meitä kohtasi se huolimattomuus, että turvauduttiin tilaisuudessa soittokunnan puhallinsoittimiin, jotka kyllä saattavat toimia hyvin ulkona vapaassa tilassa, mutta sisällä, ei niin järin suuressa salissa, soivat kuin tuomion pasuunat, kuten asiaa on tapana kuvata. Niinpä puhalsivat mainitut soittimet terveiden keuhkojen käsitteleminä tunnin sisällä melkoisen osan 31-henkisestä yleisöstä ovesta ulos, minkä johdosta uskallamme ehdottaa, että säästetään torviseitsikko kevääseen ja turvaudutaan talvella sisätiloissa "sekaorkesteriin" [blandade orkestern].

Porissa ongelmaa oli yritetty ratkaista rakentamalla Porin Raatihuoneelle, jossa useat juhlallisuudet, arpajaiset ja iltahuvit järjestettiin, soittokunnalle erillinen lehteri, jotta ääni jakautuisi tilaan tasaisemmin. Soittokunta oli äänenvoimakkuusongelman tiedostaen ottanut jo vuonna 1872 soitinvalikoimiinsa huilun ja kaksi viulua (Bj 30.11.1872), mutta niiden harjoittelu oli ilmeisesti jäänyt vähiin, koska kesällä 1877 käynnistyi keskustelu torvisoittokunnasta ja sille annettavasta kaupungintuesta. Lehtikirjoituksessa todettiin, että torvisoittokunta pystyy kyllä soittamaan teatteriesitysten väliajoilla, mutta se ei pysty säestämään laulunumeroita (вT 7.7.1877). Vaikka kirjoituksessa sitä ei suoraan mainittu, syy mitä ilmeisimmin oli soittokunnan kovaäänisyys.

Turun Soitannollisen Seuran orkesteri oli tehnyt vierailun Poriin jo syksyllä 1876. Vierailu sai lehdessä (вт 30.9.1876) kohteliaan arvion, mutta varsin vähän palstatilaa. Syksyllä 1877 tilanne oli toinen. Kapellimestari Louis Fichtelbergin johdolla esiintyneen turkulaisorkesterin kahdesta konsertista kirjoitettiin paljon sekä ennakkoon että tapahtumien jälkeen, ja sävy oli ylevä. "Orkesterikonsertin" arvostellussaan kirjoittaja kiitteli ohjelmiston "ultraklassista" ja korkeata tasoa. Ohjelmassa oli Beethovenin, Rossinin, Gluckin, Brahmsin, Stradellan, Cherubinin ja Haydnin sävellyksiä. (Bт 26.9.1877, 3.10.1877.)

Konsertissa kuultiin myös kaksi osaa Porissa tuolloin vaikuttaneen tanskalaissyntyisen Theodor Sörensenin ensimmäisestä sinfoniasta, mikä sai nimettömän arvioijan kääntymään kirjoituksensa lopuksi oman kaupungin orkesteriasiaan. Hänen mukaansa Soitannollisen Seuran konsertti oli "antanut tuoreen kokemuksen siitä, minkälaisen jalon nautinnon kauniista taideteoksesta voi kunnollinen orkesteri [ordentlig orkester] tuoda", ja vielä samassa virkkeessä hän 
asetti asiassa toivonsa Sörensenin juuri todistettuihin vakuuttaviin kykyihin (BT 3.10.1877). Teatteriesitysten säestys ei siis suinkaan ollut ainoa syy jousiorkesterin perustamiseksi. Eräskin kirjoittaja oli konsertin jälkeen sitä mieltä, että parempi olla kokonaan ilman musiikkia kuin palata torvimusiikkiin (вт 6.10.1877).

Sörensen tekikin ehdotuksen Poriin perustettavasta kymmenhenkisestä musiikkikapellista, joka pystyisi soittamaan sekä jousi- että torvimusiikkia (вт 22.9.1877, 6.10.1877). Mallia Sörensen ehdotti otettavan Turun Soitannollisesta Seurasta. Ehdotuksen seurauksena torvisoittokunta lakkautettiin, ja osa sen soittajista liittyi Sörensenin uuteen kapelliin. Ja kuin merkkinä muutoksesta uutta kapellia alettiin yhä useammin kutsua orkesteriksi (esim. вт 15.12.1877). Muutoksesta huolimatta orkesterin aktiviteetti muistutti kuitenkin huomattavasti aiemman torvisoittokunnan toimintaa. Orkesteri vastasi musiikista erilaisissa kaupungin huvi- ja juhlatilaisuuksissa. Melkeinpä ainoa ero oli se, että nyt kaupungin orkesteri pystyi säestämään myös näytelmäesitysten laulunumeroita.

Turun orkesterin tavoin myös Porin orkesteri oli "sekaorkesteri". Sisätiloissa se soitti "jousimusiikkia" kokoonpanolla, joka koostui alun perin jousikvartetista, huilusta, klarinetista, kahdesta käyrätorvesta, trumpetista ja patarummuista. Patarumpalin tehtävänä oli soittaa myös kontrabassoa. Myöhemmin hieman laajennettuaan ja ehkäpä harrastajien avustamana orkesteri kykeni jo syksyllä 1879 esittämään Beethovenin ensimmäisen sinfonian sekä Mozartin g-molli-sinfonian (BT 5.11.1879, 29.11.1879). Tarpeen vaatiessa se soitti myös "torvimusiikkia" pelkillä vaskisoittimilla. Juuri tähän Porin "sekaorkesteriin" Vaasan kirjeenvaihtaja Thomas viittasi edellä mainitussa kritiikissään, joka koski Vaasan torvisoittokunnan promenadikonserttia:

\footnotetext{
Myös Porissa annettiin promenadikonsertti tämän kuun 2. päivänä hotelli Iltaman pienemmässä salissa. Herra Gottschalksen on soittokunnastaan tehnyt jotain, joka ansaitsee tulla kuulluksi, ja me onnittelemme Porin kaupunkia siitä, että heillä on tällainen soittokunta. ( $\mathrm{U} U$ 11.10.1879.)
}

Theodor Sörensenin sairastuttua Porin orkesterin johtajan tehtävät otti hoitaakseen toinen tanskalainen, Carl Gottschalksen. Kaupunkilaiset olivat hänen ja orkesterin toimintaan hyvin tyytyväisiä. Keväällä 1882 Gottschalksen kuitenkin teki tarjouksen Helsingin kaupunginvaltuusmiehille "kaupunginorkesterin" 
(stadtskapell) ylläpitämisestä 40 ooo markan vuotuista korvausta vastaan. Tarjous hylättiin (Mbl 29.4.1882). Gottschalksen palasi Tanskaan, missä hän toimi loppuelämänsä Kööpenhaminan Tivolin kapellimestarina (Rantanen \& Heikkinen tulossa). Mutta miksi Carl Gottschalksen teki tarjouksen Helsingin kaupungille keväällä 1882? Mitä Helsingissä oli tapahtunut?

\section{Orkesterista sinfoniaorkesteriin}

Orkesteri-instituution kehitys Helsingissä 180o-luvulla noudatti monin tavoin Turun esimerkkiä, mikä ilmenee jo vuonna 1827 perustetun Musikaliska Sällskapet i Helsingfors -yhdistyksen nimessä. Kuten Turun esikuvansakin, yhdistys toimi pääasiassa amatööripohjalla. Yhdistys järjesti vuosittain 6-12 musiikillista illanviettoa, soiréeta. Ne olivat ajan tavan mukaan ohjelmistoltaan vaihtelevia ja sisälsivät alkusoittoja, sinfonioita, soolo- ja lauluesityksiä. (Dahlström \& Salmenhaara 1995: 329.) Vuonna 1844 kaupunkiin asettui ammattimuusikoista koostunut "Tyska Musikaliska Kapellet" ensin Louis Loewen ja sitten Carl Ganszaugen johdolla (FAT 4.10.1845). Kuten Siberin kapelli Turussa esiintyi Ganszaugenin kapelli erilaisissa huvitilaisuuksissa ja musiikillisissa illanvietoissa. Kesällä se soitti ravintola-asiakkaille Kaivohuoneella. Lisäksi se avusti kaupungissa vierailleita kiertäviä artisteja ja esiintyi säveltäjä Fredrik Paciuksen järjestämissä konserteissa (Dahlström \& Salmenhaara 1995: 339-340).

Syksyllä 1860 Helsinkiin valmistui uusi teatterirakennus, johon asettunutta teatteriryhmää ryhdyttiin kutsumaan Uudeksi teatteriksi (Nya Teatern). Taloon palkattiin kaksikymmenhenkinen ammattiorkesteri, jonka rungon muodosti Leipzigin konservatorioon 1850-luvulla keisarin rahoin lähetetyt seitsemän muusikkoa (Marvia \& Vainio 1993: 17). Teatterisoiton lisäksi "teatteriorkesteri" järjesti musiikillisia illanviettoja ja avusti konserteissa, kuten Ganszaugen kapelli aiemmin. Esimerkiksi vuonna 1862 teatteriesityksiä oli 145, musiikillisia illanviettoja 24, sinfoniakonsertteja 9 ja muita (ilmeisesti vierailevien taiteilijoiden) konsertteja 11 (FAT 6.2.1863). Huomionarvoista on, että myös sinfoniakonserttien nimellä mainostetut konsertit vielä tuohon aikaan olivat ohjelmistoltaan vaihtelevia ja saattoivat sisältää esimerkiksi kamarimusiikkia ja soololaulua. 1870-luvun lopulla teatteriorkesterin teatterisoittoa ja konserttitoimintaa pyrittiin erkaannut- 
tamaan siten, että helppotajuiset konsertit (populär konsert) ja sinfoniakonsertit se järjesti nimellä "Helsingfors Konsert-Orkester". Näytäntökaudelle 1881-1882 Uusi teatteri palkkasi uuden, kotimaisista soittajista koostuvan orkesterin, mikä heikensi Konserttiorkesterin taloudellista perustaa. Keväällä 1882 kapellimestari Bohuslav Hřimalý päätti lakkauttaa orkesterin toiminnan. (Marvia \& Vainio 1993: 26-27.)

Tämä oli siis tilanne, kun Gottschalksen teki tarjouksensa Helsingin kaupungille. Helsingin orkestereiden toiminta oli ollut monessa suhteessa hyvin samankaltaista kuin Porissa ja etenkin Turussa, mutta kaksi tärkeää eroa kuitenkin oli. Ensinnäkin Helsingissä ei ollut tarvetta sekaorkesterille, sillä kaupungissa toimi Suomen Kaartin sotilassoittokunta. Muista kaupungeista sotilassoittotoiminta oli 1860-luvun lopulla hiipunut tarkk'ampujapataljoonien lakkauttamisen seurauksena. Lisäksi Helsingissä kävi kesäisin paljon vierailevia sotilassoittokuntia. Esimerkiksi kesällä 1882 torvisoittoa oli lehti-ilmoitusten perusteella tarjolla melkein joka päivä, varsinkin Kaivohuoneella. Toinen ero oli se, että Helsingin kaupunki ei tukenut orkestereita. Niinpä esimerkiksi Uusi teatteri sai oman orkesterin ylläpitämiseksi taloudellista avustusta senaatilta. Tuen vastineeksi orkesteri säesti musiikkinäytelmien ja operettien laulunumeroita sekä soitti näytösten väliajoilla. (Marvia \& Vainio 1993: 26-27.)

Gottschalksen teki tarjouksen, ja niin teki Saksasta opintomatkalta saapunut Robert Kajanuskin. Kummankin anomukset kaupunginvaltuusmiehet hylkäsivät, mutta Kajanuksen onnistui saada rahoittajiksi kaksi liikemiestä. Yhdessä he perustivat yhdistyksen nimeltä Orkesterförening i Helsingfors (Helsingin Orkesteriyhdistys). Syksyllä 1882 Kajanus teki sopimuksen Ruotsalaisen teatterin kanssa, mikä takasi orkesterille taloudellisen perustan. Kajanuksen orkesterin toiminta ei juurikaan poikennut edeltävien orkestereiden toiminnasta. Sinfoniakonsertteja, joita "vakavamman" musiikin harrastajat, kuten kriitikot, pitivät toiminnan arvokkaimpana osana, järjestettiin soitantokauden aikana 7-10 kertaa. Toiminnan taloudellisen pohjan turvasivat kuitenkin teatterisoiton vastineeksi myönnetty valtionapu ja 2-4 kertaa viikossa järjestetyt helppotajuiset konsertit (Marvia \& Vainio 1993: 78-79). Vuonna 1888 myös Helsingin kaupunki alkoi tukea orkesteria, ehtonaan kymmenen "helppohintaisen" kansankonsertin järjestäminen soitantokaudessa (Marvia \& Vainio 1993: 82-92). 
Ajoittaisista vaikeuksista huolimatta Kajanuksen onnistui pitää toiminta tuottavana ja kasvattaa Orkesteriyhdistyksen orkesterin soittajalukua alun 36 muusikosta parhaimmillaan 53:een vuonna 1906. Vuonna 1894 yhdistys muuttui osakeyhtiöksi ja sai nimen Helsingfors Filharmoniska Sällskap (Helsingin Filharmooninen Seura). (Marvia \& Vainio 1993: 233, 278.) Orkesteri nautti sekä valtion että kaupungin avustusta, kunnes vuonna 1911 tapahtui käänne. Senaatti päätti puolittaa kulttuurimäärärahansa, ja orkesterit jäivät kokonaan ilman valtion tukea (Helminen 2007: 85). Kaikki orkesterin soittajat irtisanottiin vuoden 1912 alusta alkaen. Alkoi vilkas keskustelu orkesterin tulevaisuudesta.

Tilannetta kommentoi Helsingin Sanomat 30.11.1911 otsikolla "Soitto vaikenee": "Silloin loppui soitto pääkaupungista [...] Pois jäävät populäärit ja sinfoniat. Me saamme palautua alkuperäisempiin musiikkimuotoihin, kanteleeseen ja käsihanuriin, pianoon ja posetiiviin." Nimimerkki "Reporterin" mielestä ei tarvittu kahta sanaa siitä, pitääkö kaupungissa olla oma sinfoniaorkesteri:

\footnotetext{
Ellemme halua altistua sille skandaalille, että joutuisimme matkustamaan Saksaan tai Englantiin tai luoja ties minne kuullaksemme Sibeliuksen, Melartinin ja muiden teoksia, niin siksi meillä pitää olla orkesteri. Meidän täytyy saada sinfoniakonsertteja, jotka sisältyvät yleiseen tietoisuuteen ja ovat tulleet välttämättömyyksiksi. (Hbl 30.11.1911).
}

Vuoteen 1911 mennessä sinfoniakonsertit olivat muotoutuneet kutakuinkin sellaisiksi kuin ne nykyäänkin tunnetaan. Esimerkiksi 20.11.1911, hieman ennen edellä mainittuja irtisanomiskeskusteluja, Filharmoonisen Seuran orkesterin sinfoniakonsertissa ensimmäisen puoliskon ohjelmassa oli alkusoitto Mozartin Taikahuilusta ja Haydnin sellokonsertto C-duuri. Toisen puoliajan täytti Mahlerin ensimmäinen sinfonia. Eräs toinen kommentaattori esitti toiveenaan, että "valtuutetut pitäisivät meidän korkeamman musiikkielämän keskeistä ylläpitäjää, sinfoniaorkesteria, kuin hoitolapsenaan, ja huolehtisivat siitä, että se elää ja kehittyy" (DT 30.12.1911). Sinfoniaorkesterin asemaa keskeisimpänä "korkeamman" musiikin tukipilarina ei keskustelussa kukaan asettanut kyseenalaiseksi.

Populäärikonserteista oli Hufoudstadsbladetin Reporterin mukaan syytä hankkiutua kokonaan eroon. Ne olivat hänen mukaansa täyttäneet tehtävänsä, ja ravintolaorkesterit olivat ottaneen niiden paikan. Populäärikonserttien määrä oli- 
kin vähentynyt jyrkästi. Sen sijaan Reporter piti itsestään selvänä, että orkesteri edelleenkin säestää teatteri- ja oopperanäytöksissä ja avustaa vierailevia taiteilijoita.

Käsitys orkesterista, jonka päätehtävä oli pitää sinfoniakonsertteja, syntyi vähitellen. Uudessa Suomettaressa 17.9.1879 nimimerkki "Matti" kommentoi Suomalaisen teatterin orkesteritilannetta. Tulevalla näytäntökaudella näytösten väliajoille ei ollut luvassa musiikkia. "Matti" muistutti mitä "pienempikin orkesteri eli soittokunta maksaa". Hänen mielestään oli järkevää säästää "se melkoinen summa, joka olisi mennyt varsinaisen orkesterin palkkaamiseen". Hänelle orkesteri ja soittokunta eivät olleet enää synonyymeja. "Varsinaista orkesteria" ei ollut myöskään Robert Kajanus ehtinyt haalia kokoon laulaja Alma Fohströmiä säestämään syyskuun puolivälissä 1886 ennen soitantokauden alkua, ainoastaan "pikku orkesterin" (us 16.9.1886). Tampereella nimimerkki "a+b" pohti, miten Tampereen orkesteriyhdistyksen orkesteri, eli "oikea orkesteri sanan varsinaisessa merkityksessä", tulee tulevaisuudessa selviytymään, kun yleisö jatkuvasti vähenee (TU 22.1.1903). Nimimerkki "Kaikuja kansasta" sanoi asian suoraan: "Muutamat nimittävät torvisoittokuntia myöskin orkesteriksi, vaan se nimitys on väärä" (K-S 11.7.1905).

Maininnat "sinfoniaorkesterista" 1800-luvun sanomalehdissä viittasivat poikkeuksetta ulkomaisiin orkestereihin. Mielenkiintoista on sekin, että todennäköisesti ensimmäinen maininta Filharmoonisen Seuran orkesterista "sinfoniaorkesterina" on siteeraus Berliner Tageblattista, jonka Aftonposten julkaisi 16.3.1900. Jutussa kerrotaan orkesterin matkasuunnitelmista Pariisin maailmannäyttelyyn. Ylipäänsä seuran orkesteria "sinfoniaorkesterina" pitivät ensin saksankieliset lehdet, kuten seuraavana vuonna Düna-Zeitung Riiassa (Hbl 4.8.1901, 9.8.1901, 1.9.1901, 18.9.1901). Näitä kirjoituksia myös siteerattiin Suomessa laajasti. Seuraavana vuonna Oskar Merikanto muisteli kahdenkymmenen vuoden takaisia aikoja, kun "kolme niin tärkeätä musiikkilaitosta kuin sinfoniaorkesteri, musiikkiopisto ja lukkariurkurikoulu alkoivat toimintansa" (Merikanto 1902: 749). Nimitykselle saatiin virallinen vahvistus vuonna 1904, kun senaatti myönsi Helsingin Filharmooniselle Seuralle 30 ooo markkaa sinfoniaorkesterin ylläpitämiseen ( $\mathrm{Pl}$ 12.2.1904).

Syksyllä 1911 Filharmoonisen Seuran orkesteri ei ollut ainoa soittokunta, jota uhkasi lakkauttaminen. Myös Aleksei Apostolin johtama Helsingin Torvisoit- 
tokunta menetti valtionapunsa. Apostol oli perustanut torvisoittokunnan 1902 erottuaan edellisenä vuonna armeijasta protestiksi entisten joukko-osastoidensa lakkauttamiselle (Jalkanen \& Kurkela 2003: 153-154). Myöhemmin Apostol oli liittänyt kokoonpanoon myös jousisoittimia. Eräs ratkaisuehdotus ongelmaan oli molempien soittokuntien ottaminen kokonaan kaupungin haltuun "kaupunginorkesteriksi". Ajatus oli ilmeisesti melko uusi, koska musiikkikriitikko Evert Katilakin totesi, että "'[k]aupunginorkesteri' on tullut päivän tunnussanaksi" (Us 19.1.1912). Katila vastusti soittokuntien yhdistämistä yksiselitteisesti ja myös orkesterin jakamista tulevaisuudessa "pienempiin joukkueisiin, jotka esiintyisivät erinäisissä yksityisissä tilaisuuksissa, suorittamassa huvi-, ehkäpä pito-musiikkiakin [...] Kuinka tämä alentaisi orkesterin mainetta ja merkitystä taidetekijänä, on selittämättäkin ilmeistä".

Apostol teki tarkat laskelmat 75-miehisestä kaupunginorkesterista, joka hoitaisi vastaisuudessa kaiken sen musiikkitarpeen, mitä aiemmin Filharmoonisen Seuran orkesteri ja Helsingin Torvisoittokunta olivat hoitaneet: sinfoniakonsertit, torvisoiton kesäisin, modernin oopperan, tavallisen oopperan, populäärikonsertit, kuorokonsertit ja teatterimusiikin ( $\mathrm{Hbl}$ 13.2.1912). Orkesterista olisi siis tullut eräänlainen sekaorkesteri Turun ja Porin malliin. Valtuutetut eivät kuitenkaan halunneet ottaa orkesteria kaupungin haltuun, vaan päättivät myöntää seuraavaa soitantokautta varten 75 ooo markkaa sellaiselle yhdistykselle tai yksityishenkilölle, joka hoitaisi sinfoniaorkesterin ja torvisoittokunnan ylläpitämisen (HS 14.2.1912). Tehtävä annettiin Georg Schnéevoigtille, orkesterin nimeksi tuli Helsingfors Sinfoniorkester (Helsingin Sinfoniaorkesteri), ja Apostol itse jatkoi torvisoittokunnan johdossa. Järjestely ei ollut onnistunut, ja kaksi vuotta kestäneen "orkesterisodan" (ks. Marvia \& Vainio 1993: 302-313) jälkeen Helsingin kaupunki otti orkesterin lopullisesti haltuunsa ja muusikoista tuli kaupungin virkamiehiä. Nimekseen orkesteri sai Helsingfors Stadsorkester (Helsingin Kaupunginorkesteri). Populäärikonserttien määrä väheni vuosi vuodelta, kunnes kaudella 19201921 niitä ei ollut enää ollenkaan. Jonkin verran helppotajuista keskimusiikkia sisältyi vielä kansanvalistuksen nimissä annettuihin kansankonsertteihin, mutta nekin olivat osittain korvautuneet "kansan-sinfoniakonserttien" sinfonisella ohjelmistolla. Helsingin Kaupunginorkesterista oli tullut orkesteri, jonka päätehtävä oli järjestää sinfoniakonsertteja. Kulttuurinen jako kategorioihin "varsinainen taidemusiikki" ja muu musiikki oli sinetöity. 
Turussa kehitys oli samansuuntainen, mutta huomattavasti hitaampi. Vuonna 1886 Turun Soitannollinen Seura päätti luopua sekaorkesterista samalla, kun orkesterin uudeksi johtajaksi nimitettiin Karl Müller-Berghaus. Sopimukset muusikoiden kanssa tehtiin ainoastaan soittokaudeksi 1886-1887, ja kesän 1887 torvisoitto puistoissa ja huvitilaisuuksissa tilattiin alihankintana uudelleen perustetun tarkk'ampujapataljoonan soittokunnalta. Vuonna 1901, kun Suomen armeija lakkautettiin, työttömäksi jääneistä muusikoista koottiin uusi soittokunta, joka otettiin Seuran alajaostoksi, ja näin torvisoitto Turussa oli jälleen turvattu. (Eskelinen 1990: 157-158; Korhonen 2015: 178.)

Turun Soitannollisen Seuran populäärikonsertteja järjestettiin aina jatkosotaan asti, joskin syksyllä 1937 ne siirrettiin Palokunnantalosta Akatemiataloon. Muutto juhlallisempaan tilaan merkitsi sitä, että konsertit menettivät sosiaalisen seurustelun luonteensa tarjoiluineen kaikkineen ja alkoivat muistuttaa normaalia konserttia - kevyemmällä ohjelmalla tosin. Sinfoniakonserttien suhteellinen osuus lisääntyi Turussa vuosittain, ja 1960-luvulla ne olivat jo lukumääräisesti tärkein konserttityyppi. (Korhonen 2015: 316-318.) Porissa sen sijaan ensimmäinen maailmansota oli orkesteritoiminnalle kohtalokas. Soitannollista seuraa menestyksekkäästi johtanut saksalainen kapellimestari Evald Niegisch joutui sodan sytyttyä poistumaan maasta. Seuran orkesteri jatkoi toimintaansa amatööripohjalta, mutta hyvin vaatimattomin puittein. (ss 17.1.1917, sK 10.7.1918.)

\section{Johtopäätökset}

Sinfoniaorkesteri-instituution kotoistaminen Suomen kaupunkeihin oli pitkä ja monipolvinen prosessi. Amatöörimäisestä mutta ylevästä alusta Turussa siirryttiin ammattimaisiin kapelleihin, joiden tehtävä oli tyydyttää kaupunkilaisten moninaiset musiikilliset tarpeet. Näistä 180o-luvulla tärkeimpiä olivat teatterinäytösten väliajoilla soittaminen ja lauluesitysten säestäminen, musiikillisten illanviettojen järjestäminen ja kesäisin kaupunkilaisten viihdyttäminen torvisoitolla puistoissa, esplanadeilla ja kansanhuveissa. Pienemmissä kaupungeissa, kuten Porissa ja Turussa, vastuu lankesi yhdelle ja samalle soittokunnalle, mikä vaati soittajilta monipuolisuutta. Se ei kuitenkaan ollut tuon ajan ammattimuusikoille ongelma. Esimerkiksi Gustav Kock, joka 1870-luvulla soitti Helsingin 
teatteriorkesterissa viulua ja muodosti Gustaf Niemannin, Jaromír Hřimalýn ja L. Goeden kanssa maineikkaan jousikvartetin, siirtyi vuonna 1878 Jyväskylään johtamaan torvisoittokuntaa ja sieltä edelleen Vaasan pataljoonan soittokunnan johtajaksi. Lehtitietojen perusteella hän oli erinomainen es-kornetisti.

Vaikka sinfonisen ohjelmiston soittaminen oli muusikoiden ja varsinkin kriitikoiden mielestä kaupunkien orkestereiden arvokkain tehtävä, päätehtäväksi se muodostui vasta ensimmäisen maailmansodan jälkeen, ja silloinkin ensin ainoastaan Helsingin Kaupunginorkesterille. Kesti kauan ennen kuin muusikot ja kriitikot saivat kaupunkien päättävät elimet vakuuttuneiksi siitä, että kaupungin kannattaa ylläpitää orkesteria, joka soittaa pääasiassa sinfonista musiikkia. Keskimusiikkia sisältävät helppotajuiset konsertit jäivät vähitellen pois, Helsingissä jo 1920-luvun alkuun tultaessa, muualla myöhemmin.

Keskeinen osa sinfoniaorkesteri-instituutiota onkin sen kulttuurikognitiiviseen pilariin (ks. edellä s. 3) kuuluva luokittelu. 180o-luvulla "sinfoniakonsertti" saattoi sisältää melkeinpä mitä vain soolo- ja kuorolaulusta sooloviulusonaatteihin. Sinfoniakonsertin niistä teki se, että ne sisälsivät sinfonian esityksen. Vähitellen sinfoniakonsertit alkoivat pitää sisällään ainoastaan "sinfonista musiikkia". Rakenteeksi muodostui alkusoitto-konsertto-sinfonia, joka on säilynyt melko muuttumattomana meidän aikaamme saakka. Toinen merkittävä luokittelu koski musiikillisia genrejä ja niiden välisiä suhteita. "Taidemusiikki" jakautui "varsinaiseen" ja "ei-varsinaiseen", käytettiinpä juuri näitä termejä tai ei. Sinfoniakonserteissa tämä jako dramatisoitiin. Kansallinen "varsinainen taidemusiikki" liittoutui kansanmusiikin kanssa, hyökkäsi "katumusiikkia" vastaan ja suhtautui epäillen "ei-varsinaiseen taidemusiikkiin".

Kolmen kaupungin orkesteritoiminnan vertailu paljastaa mielenkiintoisesti ne eri tavat, joilla sinfoniaorkesteri-instituutio Suomessa kotoistettiin paikallisiin olosuhteisiin. Ennen 1920-lukua edes Helsingissä ei ollut mahdollista ylläpitää ammattimaista organisaatiota, joka olisi toteuttanut sen, mikä harrastajavoimin onnistui Turussa jo 179o-luvulla: orkesteri, joka keskittyy "korkeamman" sinfonisen musiikin harjoittamiseen.

Edellä mainituista eroista huolimatta mallia pyrittiin ottamaan sieltä, missä asiat näyttivät olevan paremmalla tolalla, ja siksi orkesterit ja niiden toiminta alkoivat muistuttaa hyvin paljon toisiaan. Kaupungit ja valtio tukivat orkestereita, jotka pystyivät säestämään teatteriesityksiä ja järjestämään kansanvalistuksen 
hengessä helppohintaisia populääri- ja kansankonsertteja niin sanotulle tavalliselle kansalle. Varsinkin Porissa jäljiteltiin Turun orkesterin mallia 1870-luvulla, kun organisaatio uudistettiin torvisoittokunnasta sekaorkesteriksi, joka paremmin vastasi kaupunkilaisten musiikillisia tarpeita. Olennaista olivat myös ne julkilausutut arvot ja normit, jotka muovasivat mielipiteitä suopeiksi rahoittamaan sellaista orkesteria, jonka päätehtäväksi vähitellen muodostui sinfonisen musiikin esittäminen.

Musiikillisten organisaatioiden synty ja historia ei ole kansallisesti tai paikallisesti niin omaleimaista kuin musiikinhistoriankirjoituksessa on usein annettu ymmärtää. Kansainvälisten kontaktien ja ulkomaisten muusikoiden välityksellä globaalit ideat, mallit ja instituutiot ovat muovanneet kansallisia ja paikallisia organisaatioita voimakkaasti jo ainakin 180o-luvulla, olkoonkin, että ne on kotoistettu paikallisiin olosuhteisiin sopiviksi.

\section{Lähdeluettelo}

\section{Sanomalehdet}

Bm, Barometern

Bj, Björneborg

BT, Björneborgs Tidning

DT, Dagens Tidning

FAT, Finlands Allmänna Tidning

Fw, Folkwännen

Hbl, Hufvudstadsbladet

HS, Helsingin Sanomat

Ilm, Ilmarinen

Kal, Kaleva

K-S, Keski-Savo

$\mathrm{Mbl}$, Morgonbladet

NPr, Nya Pressen

Pl, Päivälehti

SK, Satakunnan Kansa 


\section{SS, Satakunnan Sanomat}

TU, Tampereen Uutiset

US, Uusi Suometar

Vbl, Vasabladet

WS, Wiipurin Sanomat

WT, Wasa Tidning

WU, Wiipurin Uutiset

ÅT, Åbo Tidning ÅU, Åbo Underrättelser

\section{Tutkimuskirjallisuus}

Abrams, M. H. (1960) The Mirror and the Lamp. Romantic Theory and the Critical Tradition. London: Oxford University Press.

Alasuutari, Pertti, Mikola, Elina, Rautalin, Marjaana, Syväterä, Jukka \& Valkeasuo, Laura (2013)

"Globaalien kehityslinjojen luominen ja kotoistaminen". Liikkuva maailma. Liike, raja, tieto.

Toim. Mikko Lehtonen. Tampere: Vastapaino, 33-53.

Alasuutari, Pertti (2015) "The discursive side of new institutionalism". Cultural Sociology 9 (2), 162-184.

Andersson, Greger (2003) "I stadens tjänst". Gränsländer. Östersjön i ny gestalt. Toim. Janis Kreslins, Steven A. Mansbach \& Robert Schweitzer. Stockholm: Atlantis, 237-256.

Andersson, Otto (1952) Turun soitannollinen seura 1790-1808. Turku: Silta.

Broyles, Michael (2000) "Ensemble music moves out of the private house: Haydn to Beethoven".

The Orchestra. Origins and Transformations. Toim. Joan Peyser. New York: Billboard Books, $101-126$.

Dahlström, Fabian \& Salmenhaara, Erkki (1995) Suomen musiikin historia 1. Ruotsin vallan ajasta romantiikkaan. Porvoo: wsoy.

DiMaggio, Paul (1982a) "Cultural entrepreneurship in nineteenth-century Boston, I: The creation of an organizational base for high culture in America". Media, Culture and Society 4:1, 33-50.

DiMaggio, Paul (1982b) "Cultural entrepreneurship in nineteenth-century Boston, II: The classification and framing of American art". Media, Culture and Society 4:4, 303-322.

Douglas, Mary (1982) "The effects of modernization on religious change". Daedalus 1982 (Winter), 1-9. 
Edström, Olle (1992) “The place and value of middle music". Svensk Tidskrift för Music 1/1992, 7-6o.

Eskelinen, Heikki S. (1990) "Vaskisoiton vaiheilta". Turun Soitannollinen Seura 200 vuotta. Toim. Ilpo Tolvas. Turku: Turun Soitannollinen Seura, 157-169.

Gelbart, Matthew (2007) The Invention of "Folk Music" and "Art Music". Emerging Categories from Ossian to Wagner. Cambridge: Cambridge University Press.

Heikkinen, Olli (2012) "Jean Sibeliuksen Kullervo ja Larin Paraske: tarina suomalaisen sävelkielen synnystä osana kansalliskertomusta". Musiikki 42:1, 6-26.

Heikkinen, Olli (2013) "Mistä musiikki alkaa? Musiikinhistoria ja sen alku musiikkitieteen tutkintovaatimuskirjallisuudessa Helsingin yliopistossa 1923-1975". Etnomusikologian vuosikirja 25. Toim. Maija Kontukoski, Saijaleena Rantanen \& Heikki Uimonen. Helsinki: Suomen Etnomusikologinen Seura, 92-120.

Heikkinen, Olli (2018) "In search of national music. Finnish musical language and Finnish national orchestra narrated". Cultural Nationalism in a Finnish-Hungarian Historical Context. Toim. Gábor Gyáni ja Anssi Halmesvirta. Budapest: Hungarian Academy of Sciences, 62-78. Helminen, Minna (2007) Säätyläistön huvista kaikkien kaupunkilaisten ulottuville. Esittävän sävel- ja näyttämötaiteen paikallinen institutionalisoituminen ja kehitys taidelaitosten verkostoksi 1870-1939. Cuporen julkaisuja 13. Helsinki: Cupore.

Huttunen, Matti (2002) "Suomalaisen esittävän säveltaiteen historia". Suomen musiikin historia. Esittävä säveltaide. Toim. Martti Haapakoski, Anni Heino, Matti Huttunen, Hannu-Ilari Lampila \& Katri Maasalo. Helsinki: wsoy, 303-435.

Jalkanen, Pekka \& Kurkela, Vesa (2003) Suomen musiikin historia. Populaarimusiikki. Helsinki: WSOY.

Jepperson, Ronald L. (1991) "Institutions, institutional effects, and institutionalism". The New Institutionalism in Organizational Analysis. Toim. Walter W. Powell ja Paul J. DiMaggio. Chicago: The University of Chicago Press, 143-163.

Korhonen, Kimmo (2015) Sävelten aika. Turun Soitannollinen Seura ja Turun filharmoninen orkesteri 1790-2015. Helsinki: Siltala.

Krummacher, Friedhelm (1989) "Symposion "Das Nationale" - Einleitende Bemerkungen". Musiikki 1-4/1989, 87-98.

Kurkela, Vesa (2015) "Jalostavaa huvittelua: Robert Kajanuksen helppotajuiset konsertit sivistämisprojektina". Etnomusikologian Vuosikirja 27, 48-83. https://doi.org/10.23985/ evk.66776. 
Kurkela, Vesa (2017) "Helppotajuista arvokkuutta ja mandoliininsoittoa: suomalaisen keskimusiikin juurilla". Etnomusikologian vuosikirja 29, 1-37. https://doi.org/10.23985/ evk.6o930.

Marvia, Einari \& Vainio, Matti (1993) Helsingin kaupunginorkesteri 1882-1982. Porvoo: wsor.

Merikanto, Oskar (1902) "Katsaus musiikkielämäämme syksyllä 1902". Valvoja 22:12, 746-750.

Murtovaara, Arto (2005) "Umo:sta on tullut instituutio". Kaleva 18.1.2005. http:/ /www.kaleva.fi/ uutiset/kulttuuri/umosta-on-tullut-instituutio/195050 (luettu 31.3.2017).

Nilsson, Ann-Marie (2017) Musik till vatten och punsch. Krin svenska blåsoktetter vid brunnar, bad och beväringsmöten. Möklinta: Gidlunds förlag.

Nisbet, Robert A. (1969) Social Change and History. Aspects of the Western Theory of Development. Oxford: Oxford University Press.

North, Douglas C. (1990) Institutions, Institutional Change and Economic Performance. Cambridge: Cambridge University Press.

Peters, B. Guy (2012) Institutional Theory in Political Science. The New Institutionalism. 3rd edition. New York: Continuum.

Rantanen, Saijaleena (2013) Laulun mahti ja sivistynyt kansalainen. Musiikki ja kansanvalistus EteläPohjanmaalla 1860-luvulta suurlakkoon. Studia Musica 52. Helsinki: Taideyliopiston SibeliusAkatemia.

Rantanen, Saijaleena \& Heikkinen, Olli (tulossa) "Itämeren kaupunkien muusikot kaupunginmuusikkoinstituution jälkeen. Vaasan ja Porin orkesteritoiminta 1860- ja 1870-luvuilla". Trio 2/2018.

Rosas, John (1965) "Seuran toiminta 1868-1965". Turun soitannollinen seura 1790-1965. 175-vuotisjuhlajulkaisu. Toim. Marianne Ringbom. Turku: Turun Soitannollinen Seura, 30-78.

Rubin, Joan Shelley (1992) The Making of Middlebrow Culture. Chapel Hill: The University of North Carolina Press.

Ruuth, Johan Wilhelm (1899) Porin kaupungin historia. Pori: Porin kaupunki.

Schmidt, Vivien A. (2008) "Discursive institutionalism". Annual Review of Political Science 11, 303326.

Schmidt, Vivien A. (2010) "Taking ideas and discourse seriously: explaining change through discursive institutionalism as the fourth 'new institutionalism'". European Political Science Review 2:1, 1-25.

Scott, W. Richard (2014) Institutions and Organizations. Ideas, Interests, and Identities. $4^{\text {th }}$ edition. Los Angeles: Sage. 
Smeds, Kerstin \& Mäkinen, Timo (1984) Kaiu, kaiu lauluni. Laulu- ja soittojuhlien historia. Helsinki: Otava.

Tegen, Martin \& Jonsson, Leif (1992) "Musiken, kulturen och samhället. En översikt i decennier". Musiken i Sverige 3. Den nationella identiteten 1810-1920. Toim. Leif Jonsson ja Martin Tegen. Stockholm: Fischer \& Co, 19-52.

Vega, Carlos (1966) "Mesomusic. An essay on the music of the masses". Ethnomusicology 10:1, $1-17$.

Weber, William (2001) "From miscellany to homogeneity in concert programming". Poetics 29, 125-134.

Weber, William (2008) The Great Transformation of Musical Taste. Concert Programming from Haydn to Brahms. New York: Cambridge University Press.

Wuthnow, Robert (1989) Meaning and Moral Order. Explorations in Cultural Analysis. Berkeley: University of California Press. 